\title{
A Tribute to Clarence Frankton 1906-2000
}

\author{
DANIEL F. BRUNTON \\ 216 Lincoln Heights Road, Ottawa, Ontario K2B 8A8 Canada
}

Brunton, Daniel F. 2003. A tribute to Clarence Frankton 1904-2000. Canadian Field-Naturalist 117(3): 481-486.

Two events which say much about the way botanist Clarence ("Clarrie') Frankton viewed the world and the study of its natural environment occurred in midMay 2000, only weeks before his death 11 June. Although succumbing to the ravages of cancer and strokes which left him confined to his west-end Ottawa, Ontario home, he could only be described as "chipper" and even buoyant when botanical discoveries were put before him. Days earlier he had directed his wife Enid back to the shores of the Ottawa River to collect a particular specimen. Clarrie had been working on the identity of this non descript shrub since the previous fall and he was sure it would be in flower now. It was, and despite his substantial physical challenges, he worked the specimen through and determined it to be Prunus americana, precisely the rare (for the Ottawa Valley) introduced taxon that he had argued for all along. And in light of my earlier skepticism regarding that possibility, he made sure I was reminded right away how it all had turned out. His playful and inspiring competitiveness, however, was just as quickly put aside a few days later as he lauded the discovery of a locally rare native species (Cardamine bulbosa) and enthusiastically assessed the implications of the find. Clarrie was like that, always looking forward, always building upon what he already knew, always keenly anticipating the new challenge ahead.

His long-ago British beginnings were subtly, elegantly evident in his speech, with fine pronunciation and the frequent use of phrases like "quite so" and "there you have it". He was born on 6 February 1906 in Nottingham, England. His parents, William and Louise, immigrated with their only son to Montreal in 1914. William Frankton worked thereafter as an accountant for the Canadian Pacific Railway. They enjoyed a modest and happy residence in East-end Montreal and seemingly very much enjoyed that community. One of Clarrie's earliest Canadian memories was of going for a long walk with his father one day to hear a well-known politician rouse an East-end crowd into partisan fervour. The place was likely Parc Lafontaine. The politician was certainly Sir Wilfrid Laurier. Clarrie was suitably impressed and recounted the event many years later with both clarity and enthusiasm.

He left commercial high school early because of a lack of money to support continued studies and worked as an office boy at the Sun Life Insurance Company in downtown Montreal. Nonetheless, he studied privately and wrote the high school final exams, achieving the highest score in mathematics in the province of Quebec that year. He also employed his lifelong love of mathematics to good purpose while working for a time as a night accountant at the famed Algonquin Hotel in

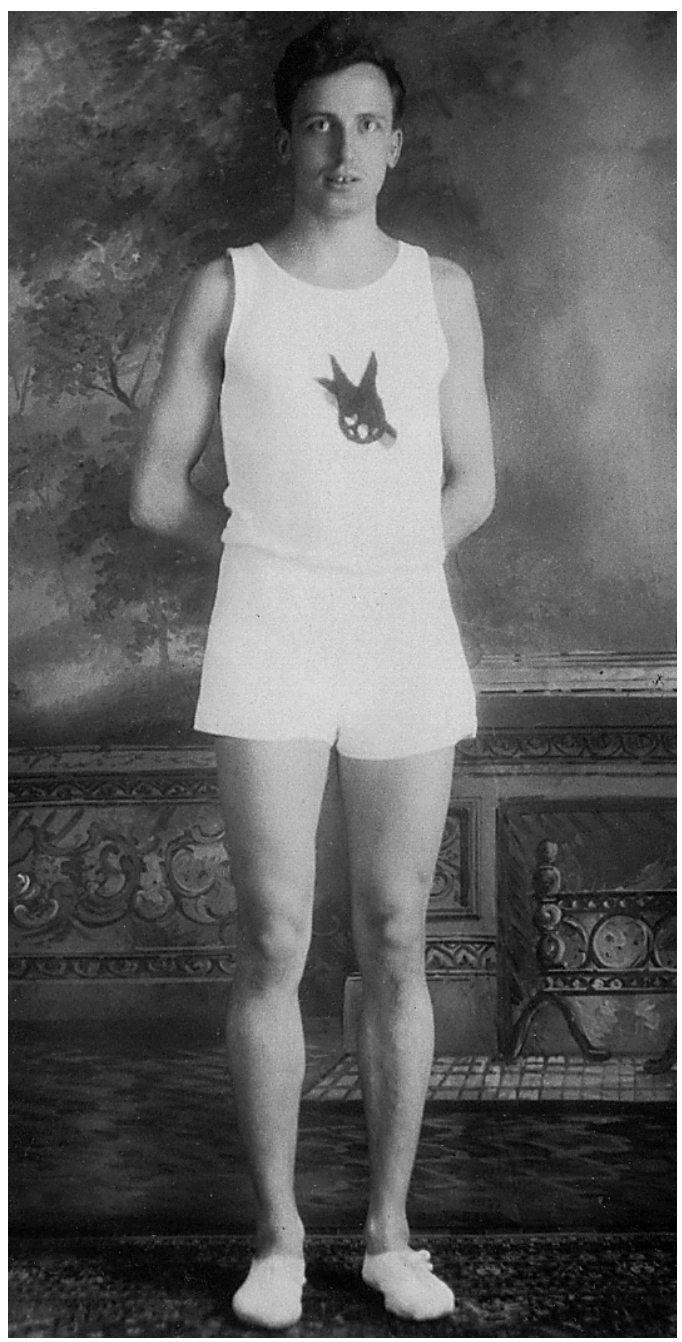

Clarrie Frankton in Montreal Amateur Athletic Association uniform ca. 1932 (photo courtesy of Enid Frankton) 
St. Stephen, New Brunswick. His daughter Gwen (Coffin) aptly described his mathematical passion in her tribute delivered at a well-attended remembrance celebration in June 2000 " ... he loved the idea of it, loved its practice. He really enjoyed doing his taxes! In the hospital after his first stroke he was reading Mathematics for the Millions, a loved and tattered volume".

When finances permitted, Clarrie entered into the general B. Sc. program at McGill University where he soon discovered an interest in botany. Despite an enjoyment of countryside rambles, neither his parents nor personal associates directly inspired his subsequent calling. He came to that discovery in undergraduate school, soon delighting in botany as a science and in field-based research as an approach. He was spurred to take an ecological, interdisciplinary view of botanical questions by several prominent professors of the day, including F. E. Lloyd, G. W. Scarth and V. C. WynneEdwards. He graduated with a Ph.D. from McGill in 1946, his doctoral thesis addressing the ecology of pasture grasses of Quebec.

Up to and throughout his university years, Clarrie was also a serious and highly successful long-distance runner and a member of the renowned Montreal Amateur Athletic Association. He accumulated a remarkable number of ribbons, medals and trophies during this period for victories in various cross country categories. And this racing went on year round too, as he also competed in winter on snowshoes. On at least one occasion in the 1930s he won the World Snowshoe Championships conducted during the Quebec Winter Fair. Clarrie remained astonishingly fit and a keen "walker" into his 90s. He was quite capable and mischievously keen to walk much younger associates into the ground when he was in his mid-80s. (I can present scars as proof!). He held absolutely no fear of bush-whacking, be that through marsh, buckthorn thicket or seemingly impenetrable cedar bush, if there was the promise of a good plant record in it.

When he completed his university studies Clarrie first found employment conducting pasture research with the Quebec Department of Agriculture, much of his field work being conducted in the Eastern Townships. His recall of events, sites and discoveries in those years was uncanny. These bits of understanding were regularly brought forward decades later, not as "good old days" reminiscences but as pertinent insights to be effectively applied to a question before us in the present day.

Clarrie's provincial Department of Agriculture employment ended in 1946 when he resigned to protest a maneuver which apparently saw the replacement of his supervisor (Dr. Carl Raymond) with a political appointee. While visiting the Botany Department at McGill shortly thereafter, however, and "in between positions" as he later put it, he struck up a conversation with Harold Senn, visiting head of the Botany Unit of the federal Department of Agriculture (later,
Agriculture Canada) at the Central Experimental Farm in Ottawa, Ontario. Senn, who recruited a remarkable team of field botanists and taxonomists during the 1940s and early 1950s (Cody 1997), was obviously impressed. Two days later a letter arrived from Ottawa offering Clarrie an opportunity to join the Botany Unit's Weed Survey program, working with the venerable Herb Groh who constituted a direct link to James Fletcher, John Macoun, and other Victorian pioneers of Canadian field botany (Taschereau 1972). They jointly prepared two editions of the Canadian Weed Survey in the late 1940s (Appendix 1). After Groh retired in 1948, Clarrie headed up and maintained the Weed Unit into the 1960s (Cody et al., 1986).

When he arrived at the Botany Unit's main building in Ottawa, Clarrie asked the first person he saw for directions to Senn's office. The helpful guide was botanical technician Enid Patterson with whom he would be married less than two years later. Although she retired when they were married (this was the postwar, late 1940s!) Enid remained keenly involved in natural history investigations. She applied her botanical training and personal interest with particular success after Clarrie retired, the two forming an unsurpassed team of floristic investigators in eastern Ontario and western Quebec.

Although attending to a broad sweep of floristic and taxonomic studies, Clarrie's professional focus began and remained with agriculturally troublesome weeds and their associated species. His field and herbarium expertise provided early identification of a number of previously unrecognized but now at least regionally significant weeds such as Erysimum hieraciifolium and Salsola collina. Clarrie is probably most widely known, however, for his authorship of Weeds of Canada which served as a major source of information on these economically important plants for decades. Later versions of this standard work were revised with Agriculture Canada colleague Gerry Mulligan. With Ray Moore, Clarrie also co-authored an authoritative book on the thistles of Canada (Appendix 1).

In a career spanning 1946 through 1970 with the botanical research group at the Central Experimental Farm (officially known as The Botany Unit, The Botany Division and the Plant Research Institute at various times but always referred to by researchers and regular visitors alike as "The Farm"), Clarrie held a variety of official positions. These included Chief of the Weed Investigation Section, Chief of the Taxonomy and Economic Botany Section, Associate Director of the Institute and for a two-year period, Acting Director of the Institute (Steeves 1973).

During this time he conducted a wide variety of research into various economic weed questions, working with a diversity of associates such as Herb Groh, Gerry Mulligan, John Bassett, Jim Calder and Bernard Boivin. His co-operative and generous nature and keen interest made him a much appreciated research collaborator 


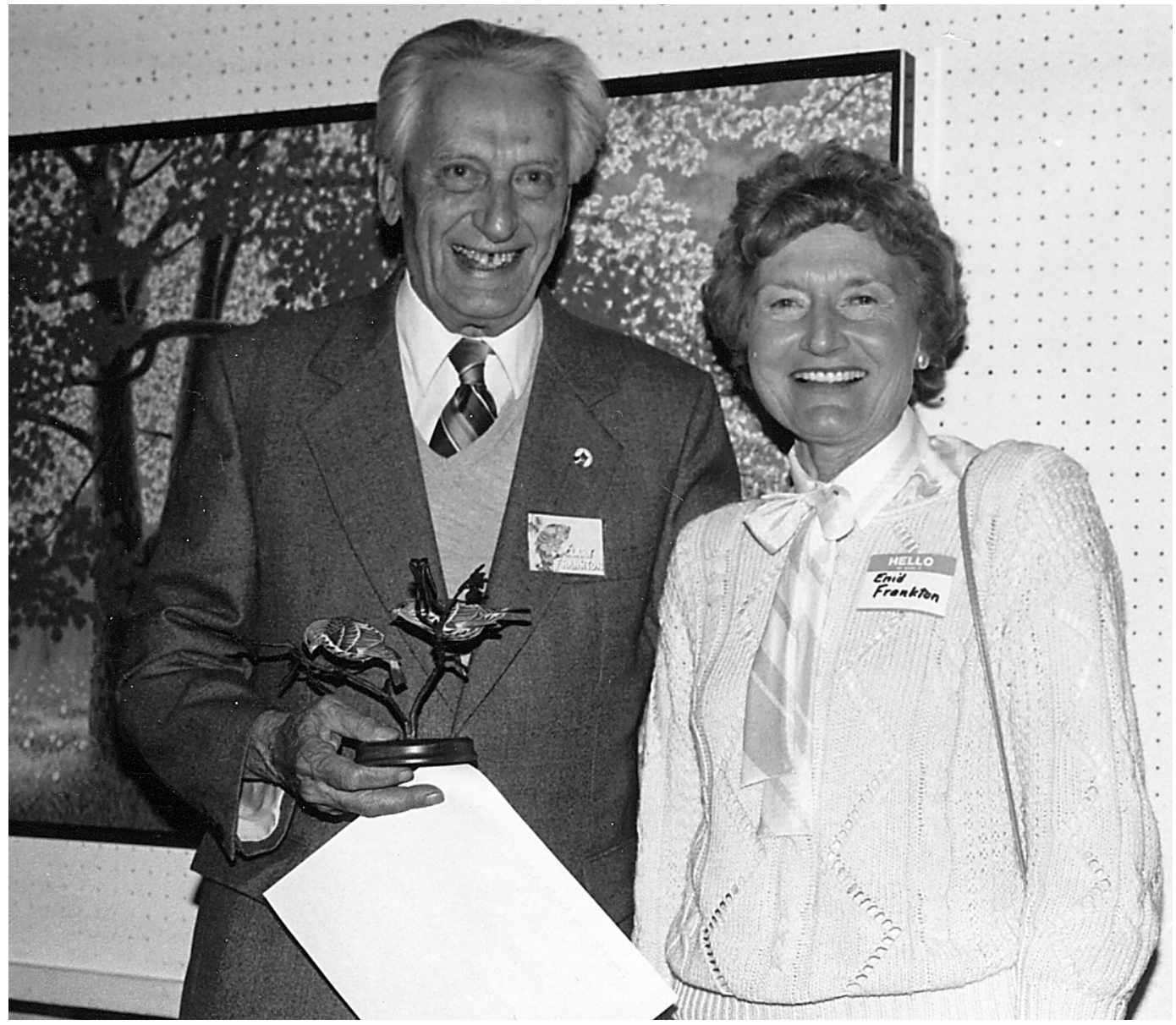

Clarrie and Enid Frankton, following Clarrie's receipt of 1986 Anne Hanes Natural History Award (April 1987)

who was known to bring rare and unusual skills to bear to the problems at hand. In the late 1950 s and early 1960s, for example, he taught himself sufficient scientific Russian to satisfactorily translate appropriate sections of the mammoth Flora of the USSR as various volumes appeared, both for his own research purposes and for the benefit of his associates at The Farm.

Clarrie became an internationally recognized authority on many species of the economically important genera Cirsium, Carduus, Atriplex, Rumex and Polygonum (sensu lato). In collaboration with several associates (Appendix 1), Clarrie recognized many previously undetected taxonomic relationships and made significant improvements to the classification of taxa within these genera through the application of cytological data from Canadian specimens.

During this 25-year professional career Clarrie also developed a huge and loyal network of contacts and correspondents throughout Canada and beyond, including agricultural representatives, taxonomists and weed specialists. Although he traveled rarely, his network of contacts served him well. In addition to his professional associates at The Farm, his correspondents contributed much of the living and preserved plant material he required for his various investigations.

It is fair to say that Clarrie was a true scholar, one who valued the intellectual challenge of scholarship for its own sake and one who also cared deeply about its consequences. His natural sciences research was no ivory tower occupation. Much of his definitive work on weed species was of direct economic value to thousands of Canadian farm families and to the agricultural economy.

Although a prolific collaborator, he only relatively infrequently initiated publications (Appendix 1). Clarrie was perfectly content to leave it to associates and partners to incorporate his data and analysis within their work. Had he not been a taxonomist, however, he most certainly could have been a technical editor. He had an incredibly sharp eye for typographical 
errors, factual inconsistencies and structural problems in the most complex and convoluted technical writing. He was particularly alert - no, eager - to point out spelling errors. Most of the scientific journal papers submitted from the botanical research group during his years at The Farm benefited greatly from his input. Many of those contributions to staff manuscripts were deemed worthy of co-authorship but Clarrie consistently refused, stating modestly that he was just doing his duty (C. Crompton, personal communication). The substantial impact and importance of his scholarship is expressed by appreciative associates through their appellation of such taxa as Atriplex franktonii, Polygonum franktonii and Cirsium undulatum var. franktonis (Taschereau (1972a), Wolf and McNeill (1986) and Boivin (1972), respectively).

While he was a member of and often active within many professional and non-professional organizations including the Canadian Botanical Association, The Ottawa Field-Naturalists' Club, Nature Saskatchewan, etc., he rarely served in official capacities. It should be noted, however, that he distinguished himself during two exceptions to this rule, in both cases remedying major organizational problems. As Ottawa FieldNaturalists' Club Treasurer (1947 - 1948) he undertook to sort out the disarray in Club finances which had arisen in large measure by sloppy attention to Canadian Field-Naturalist back-issue and reprint orders - a major source of revenues in those days. He and Canadian Field-Naturalist Business Manager Bill Cody worked mightily re-organizing the orders, many of which had been ignored for months and even years by a distracted editor, salvaging many of the invoices and thus generating a significant and sudden influx of revenue. That income became the investment foundation upon which the substantial equity which the organization presently enjoys was built. The situation was made all the trickier by the fact that the "distracted editor" in question was none other than their supervisor, Harold Senn!

Later, Clarrie served as Secretary-General of the $9^{\text {th }}$ International Botanical Congress held in Montreal in August 1959. Called into the position only in late 1958, he used his organizational expertise to clear up serious logistical and organizational difficulties and ensure the successful achievement of the Congress programs.

In recognition of his years of scientific contributions he received the George Lawson Medal (lifetime achievement award) of the Canadian Botanical Association in 1973 (Steeves 1973). He was made an Honorary Member of the Ottawa Field-Naturalists' Club in 1980 (Brunton 1981), of which he was a member for 54 years. He had been considered for the Honorary Membership years before, largely in recognition of his critical role in organizing the 1959 Montreal International Botanical Congress. It was correctly felt at the time, however, that there would be plenty of other reasons, both local and national in scope, to recognize him with this honour in later years (1961 Awards Committee notes, Ottawa Field-Naturalists' Club collection, Public Archives of Canada).

Clarrie also served as advisor on agricultural science and botanical research matters to the Royal Commission on Government Organization (the 1962 Glassco Commission) which led to substantial re-organization of the way federal government departments were organized and operated. His efforts in this difficult and at times frustrating task were reportedly greatly appreciated both by Commission members and the agricultural research community (C. Crompton, personal communication).

Throughout all this, Clarrie was very active in floristic investigations in the National Capital Region, particularly so after he retired in 1970 . He focused especially on a number of the most ecologically significant areas within the vast National Capital Greenbelt which surrounds the urban core of Ottawa. Here and elsewhere he and Enid discovered literally dozens of new records of regionally and provincially significant vascular plant records. Significant native rarities they discovered as new in the Ottawa District include the provincially significant Huperzia selago and Woodsia oregana ssp. cathcartiana, and the regionally significant (viz., rare within the City of Ottawa (former Region of Ottawa-Carleton)) Asplenium platyneuron, Spiranthes casei, Claytonia virginica, Polygala verticillata, Viola rostrata and Bidens discoideus (Brunton 1998). And to this can be added many more first records for weedy species. This is a particularly impressive achievement in that the Ottawa District (the area within a $50 \mathrm{~km}$ radius of the Parliament Buildings in Ottawa) must surely be one of the most thoroughly botanized localities in Canada. Such lasting contributions as these were acknowledged in his $80^{\text {th }}$ year when the Ottawa Field-Naturalists awarded him the 1986 Anne Hanes Natural History Award "for outstanding contributions to the study of natural history of the Ottawa Valley".

Clarrie's field explorations have also proven to be of critical importance to conservation efforts in the National Capital Region. Only months after his death, a magnificent, 250 ha-block of provincially significant forest, pond and rock barren landscape in the South March Highlands of Kanata (now within the City of Ottawa) was formally designated a natural environment reserve by the municipality. The major ecological rationale for this important, $\$ 1.6$ million public conservation initiative was substantially formed by Clarrie's definitive field investigations.

Beyond all that, though, Clarrie's greatest contribution may have been his ability to inspire others. He was very much one of that band of post-war Canadian natural scientists including the late Earl Godfrey, George Ledingham, Bill Dore, Bernard Boivin and Bill Baldwin whose passion for their work - their calling, really - was readily transferred to others. 
Clarrie shared with them a love of scholarship and was thrilled by the discovery process itself. And like those other noted scientists, he both respected and encouraged anyone involved in it, be they high powered professionals or concerned citizens. More than a few research scientists and ecological specialists, including Gerry Mulligan, former Director of the Agriculture Canada Biosystematics Research Institute, botanists Pierre Taschereau, and Cliff Crompton, entomologist J. Donald Lafontaine and this writer, have been proud to acknowledge the importance of Clarrie's encouragement and guidance in the development of major aspects of their professional careers.

Although pleased by the praise and honours of his peers, Clarrie might well have most appreciated being recognized as a true "amateur", one who undertakes an activity for the sheer love of it. He was always looking forward to new inquiries to be undertaken, new questions to be answered. Indeed, in his $95^{\text {th }}$ year he remained as he had been for almost four decades, the "youngest" man I knew. His is a difficult though inspirational act to follow, but of that challenge I am sure Clarrie would simply have said, "there you have it".

Well ... quite so.

\section{Acknowledgments}

Enid Frankton and Gwen provided important details on Clarrie's early years and family background and granted permission for the use of the photographic portrait from his athletic years. Bill Cody contributed a number of additions to the list of publications and Gerry Mulligan, Cliff Crompton, Carmen and Madeline Patterson, Karen McIntosh and Vic Sims shared valuable anecdotes, memories and perspectives on this remarkable individual. Important contributions were also provided by the thoughtful reviews of an earlier draft of this manuscript by Jacques Cayouette, Paul Catling and especially Cliff Crompton, former associates of Clarrie's at The Farm.

\section{Literature Cited}

Boivin, B. 1972. Flora of the Prairie Provinces Part III. Provancheria 4 Quebec. Pages 1-224.

Brunton, D. F. 1981. New Honorary Members of the Ottawa Field-Naturalists' Club. Canadian Field-Naturalist 95: 478-80.

Brunton, D. F. 1998. Distributionally significant vascular plants of the Region of Ottawa-Carleton. Planning and Development Approvals Department Report \#28-09, Regional Municipality of Ottawa-Carleton, Ottawa.

Cody, W. J. 1997. A Tribute to Harold Archie Senn, 1912 1997. Canadian Field-Naturalist 111: 671-675.

Cody, W. J., D. B. O. Savile, and M. J. Sarazin. 1986. Systematics in Agriculture Canada at Ottawa 1886 1986. Agriculture Canada Historical Series Number 28, Ottawa.

Small, E., J. Cayouette., B. Brookes, and W. Wojtas. 1995. Canadian Biodiversity: a Guide to Botanical Specialists and Literature. Agriculture and Agri-Food Canada, Research Branch, Central Experimental Farm, Biological Resources Division, Ottawa.

Steeves, T. A. 1973. Presentation of Lawson Medals by the President of the CBA/ABC.The Canadian Botanical Association Bulletin 6 (3): 4-6.

Taschereau, P. 1972a. In memoriam: Herbert Groh. Canadian Field-Naturalist 86: 299-306.

Taschereau, P. 1972b. Taxonomy and distribution of Atriplex species in Nova Scotia Canadian Journal of Botany 50: 1571-1574.

Wolf, S. J., and J. McNeill. 1986. Synopsis and achene morphology of Polygonum Section Polygonum (Polygonaceae) in Canada. Rhodora 88: 457-479.

Received 1 December 2002

Accepted 31 October 2003

\section{Appendix 1: Chronological bibliography of Clarence Frankton}

[adapted from Small et al., (1995), with additions provided by W. J. Cody]

Frankton, C., and L. C. Raymond. 1941. An ecological and crop survey of Stanstead County. Macdonald College Pasture Studies XX. Scientific Agriculture 22: 178-194.

Frankton, C., and L. C. Raymond 1944. Pasture succession in the Eastern Townships of Quebec. Macdonald College Pasture Studies XXV. Scientific Agriculture 24: 271-281.

Frankton, C. 1948. Review of: Campagna, "Le problème de l'Herbe à Poux (Ambrosia artemisiifolia) (Ambrosia trifida), en Gaspésie.” Canadian Field-Naturalist 62: 166.

Frankton, C. 1948. Review of: "1946 Annual report of the Provancher Society of Natural History." Canadian FieldNaturalist 62: 166.

Frankton, C. 1948. Review of: Florence Page Jacques, "Canadian Spring." Canadian Field-Naturalist 62: 166.

Groh, H., and C. Frankton. 1948. Canadian weed survey, fifth report, 1946. Canada Department of Agriculture, Ottawa. 86 pages.
Frankton, C. 1949. Review of: 1947 Annual report of the Provancher Society of Natural History. Canadian FieldNaturalist 63: 214.

Groh, H., and C. Frankton. 1949. Weed surveys in Canada. Agricultural Institute Review 4: 150-152.

Groh, H., and C. Frankton. 1949. Canadian weed survey, sixth report, 1947. Canada Department of Agriculture, Ottawa. 25 pages.

Groh, H., and C. Frankton. 1949. Canadian weed survey, seventh report, 1948. Canada Department of Agriculture, Ottawa. 144 pages.

Frankton, C., I. J. Bassett, and F. Forsyth. 1949. Comparison by bio-assay tests of 2,4-D esters of high surface activity with 2,4-D formulations now in use. Pages 76-77 in Proceedings of the $2^{\text {nd }}$ meeting, Eastern Section, National Weed Commission.

Frankton, C. 1950. Review of: South Nation Valley Interim Report, 1948. Canadian Field-Naturalist 64: 190. 
Bassett, I. J., and C. Frankton. 1952. Canadian havens from hay fever. Canadian Government Travel Bureau, Northern Affairs and National Resources. 30 pages. [2nd edition - 1955; 3rd edition - 1957; 4th edition - 1958; 5th edition - 1960; 6th edition - 1962.]

Frankton. C. 1954. A new weed, Erysimum hieraciifolium L. in Canada. Canadian Field-Naturalist 68: 27- 28.

Moore, R. J., and C. Frankton. 1954. Cytotaxonomy of three species of Centaurea adventive in Canada. Canadian Journal of Botany 32: 182-186.

Mulligan, G. A., and C. Frankton. 1954. The plumeless thistles (Carduus ssp.) in Canada. Canadian Field-Naturalist 68: 31-36

Frankton, C., and R. J. Moore. 1961. Cytotaxonomy, phylogeny, and Canadian distribution of Cirsium undulatum and Cirsium flodmanii. Canadian Journal of Botany 39: 21-33.

Moore, R. J., and C. Frankton. 1962. Cytotaxonomic studies in the tribe Cynareae (Compositae). Canadian Journal of Botany 40: 282-293.

Moore, R. J., and C. Frankton. 1962. Cytotaxonomy and Canadian distribution of Cirsium edule and Cirsium brevistylum. Canadian Journal of Botany 40: 1187-1196.

Mulligan, G. A., and C. Frankton. 1962. Taxonomy of the genus Cardaria with particular reference to the species introduced into North America. Canadian Journal of Botany 40: 1411-1425.

Bassett, I. J., G. A. Mulligan, and C. Frankton. 1962. Poverty weed, Iva axillaris, in Canada and the United States. Canadian Journal of Botany 40: 1243-1249.

Selleck, G. W., R. T. Coupland, and C. Frankton. 1962. Leafy spurge in Saskatchewan. Ecological Monographs 32: 1-29.

Frankton. C., and R. J. Moore. 1963. Cytotaxonomy of Cirsium muticum, Cirsium discolor, and Cirsium altissimum. Canadian Journal of Botany 41: 74-84.

Frankton, C., and R. J. Moore. 1963. Cytotaxonomic notes on some Cirsium species of the Western United States. Canadian Journal of Botany 41: 1554-1567.

Moore, R. J., and C. Frankton. 1964. A clarification of Cirsium foliosum and Cirsium drummondii. Canadian Journal of Botany 42: 452-461.

Moore, R. J., and C. Frankton. 1965. Cytotaxonomy of Cirsium hookerianum and related species. Canadian Journal of Botany 43: 597-613.

Moore, R. J., and C. Frankton. 1966. An evaluation of the status of Cirsium pumilum and Cirsium hillii. Canadian Journal of Botany 44: 581-595.
Moore, R. J., and C. Frankton. 1967. Cytotaxonomy of foliose thistles (Cirsium spp. aff. C. foliosum) of western North America. Canadian Journal of Botany 45: 1733-1749.

Mulligan, G. A., and C. Frankton. 1967. Present status of tall wormseed mustard, Erysimum hieraciifolium in Canada. Canadian Journal of Botany 45: 755-756.

Frankton, C., and I. J. Bassett. 1968. The genus Atriplex (Chenopodiaceae) in Canada. I. Three introduced species: A. heterosperma, A. oblongifolia and A. hortensis. Canadian Journal of Botany 46: 1309-1313.

Moore, R. J., and C. Frankton. 1969. Euphorbia $\times$ pseudo-esula (E. cyparissias $\mathrm{x}$ E. esula) in Canada. Canadian Field-Naturalist 83: 243-246.

Moore, R. J., and C. Frankton 1969. Cytotaxonomy of some Cirsium species of the eastern United States, with a key to eastern species. Canadian Journal of Botany 47: 1257-1275.

Frankton, C., and I. J. Bassett. 1970. The genus Atriplex (Chenopodiaceae) in Canada. II. Four native western annuals: A. argentea, A. truncata, A. powellii and A. dioica. Canadian Journal of Botany 48: 981-989.

C. Frankton, and G. A. Mulligan. 1970. Weeds of Canada. Canada Department of Agriculture Publication 968. 217 pages.

Cody, W. J., and C. Frankton. 1971. Ragged robin, Lychnis flos-cuculi L. (Caryophyllaceae) in Canada. Canadian Field-Naturalist 85: 256-257.

Frankton, C. 1972. Review of: Carl Bode, "The best of Thoreau's Journals." Canadian Field-Naturalist 86: 110.

Mulligan, G. A., and C. Frankton. 1972. Chromosome races in Rumex arcticus (Polygonaceae). Canadian Journal of Botany 50: 378-380.

Moore, R. J., and C. Frankton. 1974. The Cirsium arizonicum complex of the southwestern United States. Canadian Journal of Botany 52: 543-551.

Moore, R. J., and C. Frankton 1974. The thistles of Canada. Research Branch, Canada Department of Agriculture, Monograph Number 10. 112 pages.

Bassett, I. J., C. W. Crompton, and C. Frankton. 1976. Canadian havens from hay fever (revised). Agriculture Canada Publication 1570. 21 pages.

Frankton, C., and G. A. Mulligan. 1987. Weeds of Canada (revised edition). NC Press Ltd., Toronto. 217 pages.

Frankton, C., and G. A. Mulligan. 1988. Les plantes nuisibles du Canada (revisée). Marcel Broquet Inc., Montréal. 218 pages. 